Çukurova Üniversitesi Mühendislik Mimarlık Fakültesi Dergisi, 32(4), ss. 55-62, Aralık 2017

Çukurova University Journal of the Faculty of Engineering and Architecture, 32(4), pp. 55-62, December 2017

\author{
Design and Analysis of Hydraulic Truck Unloading Platforms \\ Erinç ULUDAMAR ${ }^{* 1}$, Gökhan TÜCCAR ${ }^{2}$ \\ ${ }^{1}$ Adana Bilim ve Teknoloji Üniversitesi, Mühendislik Fakültesi, Otomotiv Mühendisliği Bölümü, \\ Adana \\ ${ }^{2}$ Adana Bilim ve Teknoloji Üniversitesi, Mühendislik Fakültesi, Makine Mühendisliği Bölümü, \\ Adana
}

Geliş tarihi: 17.07.2017

Kabul tarihi: 19.12.2017

\begin{abstract}
One of the most efficient ways of unloading undumped trucks are using Hydraulic Truck Unloading Platforms (HTUP). HTUPs should be designed carefully by considering the reliability of the platform and its material cost. Therefore, in this study, three different HTUP designs were compared by considering its stress distribution at different operational positions and their costs. CATIA V5 and ANSYS Workbench software programs were used in order to prepare three-dimensional models of the platforms and their structural analyses. Structural analysis indicated that maximum von-Mises stress distribution of platforms are between 93,41 MPa and 210,29 MPa. The materials of the frame were selected according to stress distribution. Material costs of the frames were compared and the results were presented, as well. It was also found that von-Mises stresses on the frame of the platform are higher at horizontal position than the $45^{\circ}$ inclined position.
\end{abstract}

Keywords: Hydraulic truck unloading platform, Finite element analysis, Design

\title{
Hidrolik Kamyon Boşaltma Platformlarının Dizayn ve Analizi
}

\section{$\ddot{O} z$}

Dampersiz kamyonların yükünün boşaltılmasının en verimli yolundan birisi Hidrolik Kamyon Boşaltma Platformlarının (HKBP) kullanılmasıdır. HKBPler dizayn edilirken platformun güvenilirliği ve malzeme maliyeti göz önünde alınmalıdır. Bu sebeple, bu çalışmada, üç farklı HKBP tasarımı farklı operasyon pozisyonlarındaki gerilme dağılımları ve maliyeti düşünülerek karşılaş̧ııılmıştır. CATIA V5 ve ANSYS Workbench yazılım programları üç boyutlu modellerin hazırlanması ve bu modellerin gerilme analizleri için kullanılmıştır. Yapısal analiz sonuçları en yüksek von-Mises gerilme dağılımlarının 93,41 MPa ve 210,29 MPa arasında olduğunu göstermiştir. Yapıda kullanılan malzemeler gerilme dağılımlarına göre seçilmiş̧ir. Malzeme maliyeti karşılaştııılmış ve sonuçları da sunulmuştur. Ayrıca platform yapısının von-Mises gerilmelerinin yatay pozisyonda $45^{\circ}$ eğik pozisyona göre daha yüksek olduğu bulunmuştur.

Anahtar Kelimeler: Hidrolik kamyon boşaltma platformu, Sonlu elemanlar analizi, Dizayn

\footnotetext{
*Sorumlu yazar (Corresponding author): Erinç ULUDAMAR, euludamar@adanabtu.edu.tr
} 


\section{INTRODUCTION}

Loading and unloading operation is a crucial operation for logistic. The operation has to be quick without damaging goods on truck vessel. Hydraulic Truck Unloading Platforms (HTUP) are used to unload dry bulk products from the truck rapidly and efficiently. HTUPs are manufactured in many countries by several manufacturers. Due to the economic and social problems in all over the world, the product of the manufacturers must be optimized in many ways. The products should minimize the cost by considering performance requirement in terms more desirable by the costumers [1].

Nowadays, numerical methods have gained great importance to overcome mechanical problems [2]. Finite Element Method (FEM) is an efficient tool to predict linear and nonlinear behavior of structural elements before prototyping [3-4]. In recent years, structure analysis of platforms and frames gained great importance. Bošnjak, Gnjatović, Momčilović, Milenović and Gašić (2015) investigated stress states in the critical zone of a mobile elevating work platform with the aid of FEM [5]. Ren, Yu, Zhao, Fan, Li modelled in order to find out optimal design of the frame of a dump truck [6]. Covill, Blayden, Coren and Begg (2015) used parametric FEM in order to examine of road bicycle frames with different tube profiles [7]. Stress analyses of low loader structure which is consist of I-beams were performed by Nor, Rashid, Mahyuddin, Azlan and Mahmud 2012 [8]. Researches on composite structure material has also gained importance in all over the world. Hadi and Yuan were investigated four composited beams and compared them with conventional beam under four point bending force [9]. Rivera, Aguilar, Cardenas, Elizalde and Probst (2016) studied on thin-walled composite beams [10]. They investigated the materials under fatigue loads.

In present study, three different HTUP's frames were compared with the aid of finite element method. The frame materials were decided according to their stress distribution, and then their cost were calculated.

\section{MATERIAL AND METHODS}

In this study, HTUPs were designed via CATIA V5 software program. I-profiles and box profiles of the platforms were prepared in structure design module of the software (Figure 1). The lengths of the platforms are $16700 \mathrm{~mm}$ for HTUP-1, $16600 \mathrm{~mm}$ for HTUP-2 and HTUP-3 while all of them have $3100 \mathrm{~mm}$ width. Peripheries of the HTUPs were made up by $200 \times 100 \times 5 \mathrm{~mm}$ box profiles. I-profiles were used to combine the frames of the platforms the profiles are; IPE100, IPE200, and IPE 500. The frames of the platforms were illustrated in figures 2, 3, and 4 and some physical properties of them are given in Table 1 .

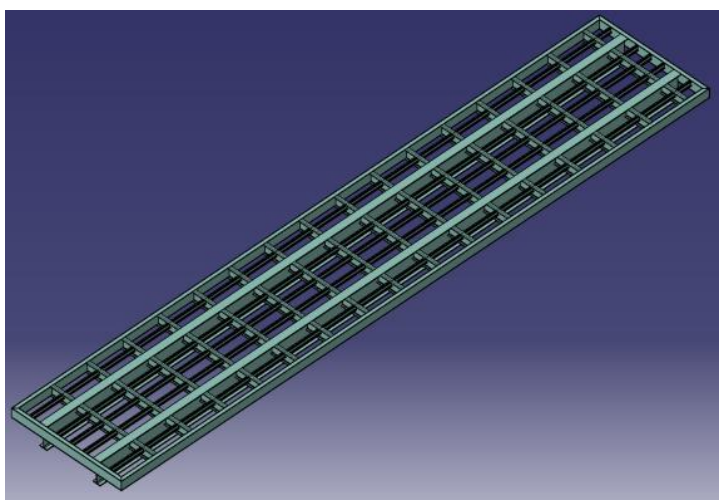

Figure 1. 3D model of platform's frame

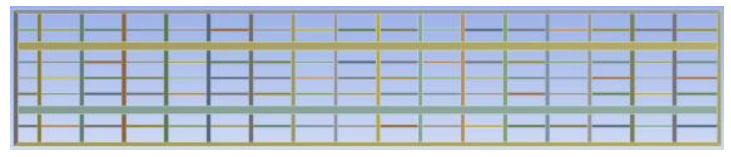

Figure 2. Frame of HTUP-1

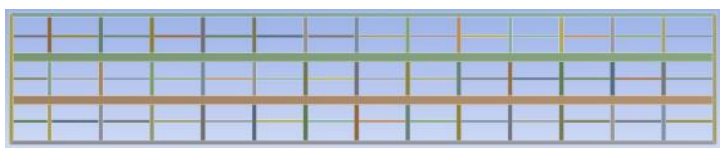

Figure 3. Frame of HTUP-2

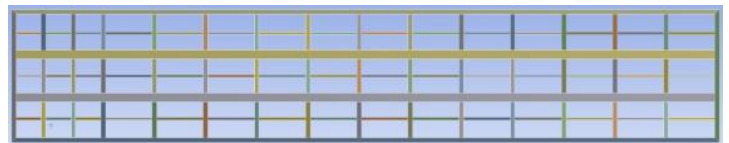

Figure 4. Frame of HTUP-3 
The designed three-dimensional models were imported to ANSYS Workbench environment without any simplification on the models. The same properties of a steel were applied to the models which have; 2E+11 Pa Young's Modulus, 0.3 Poisson's Ratio. Number of elements and nodes of the models are given in table 1. All analyses were carried out with a workstation, which has 2 processors (24 cores) and 32 GB RAM.

Table 1. Basic properties of frames

\begin{tabular}{|c|c|c|c|c|}
\hline & & HTUP-1 & HTUP-2 & HTUP-3 \\
\hline 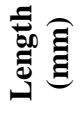 & & 16700 & 16600 & 16600 \\
\hline 昰 & & 3100 & 3100 & 3100 \\
\hline 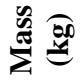 & & 5615.7 & 5055.8 & 5116.4 \\
\hline \multirow{3}{*}{ 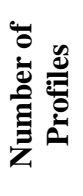 } & IPE100 & 85 & 42 & 45 \\
\hline & IPE200 & 48 & 39 & 42 \\
\hline & IPE500 & 2 & 2 & 2 \\
\hline \multirow{2}{*}{ 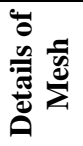 } & Nodes & 2414343 & 1446134 & 1620531 \\
\hline & Elements & 1257421 & 724608 & 831477 \\
\hline
\end{tabular}

I- beams which are usually made of structural steel are very popular in construction of platforms due to their high strength with low material usage [11]. In this study, frames of the HTUPs were consists of European standard I sections; IPE100, IPE200, and IPE500 which have a cost of, respectively

\section{Loading and Boundary Conditions}

The frames of the platforms were analyzed in two different conditions. At both conditions, HTUPs were fixed from the pin points which were shown in figure 5. The forces simulate the own weight of platforms and double weight of a loaded truck in order to satisfy safety factor. At the first scenario, loads were applied according to truck weight is perpendicular to platform which represents truck weight in order to simulate the forces exert on when it is horizontal with the ground $\left(0^{0}\right.$ inclined $)$. At the second scenario, loads were applied in order to simulate the platforms which have $45^{\circ}$ inclined position from the ground. In figures 7 and 8 pin points and loads at two scenarios are shown.

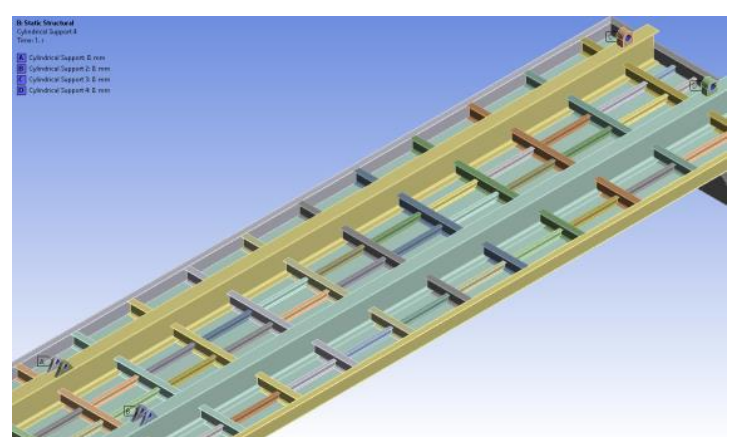

Figure 5. Fixed points of the platforms

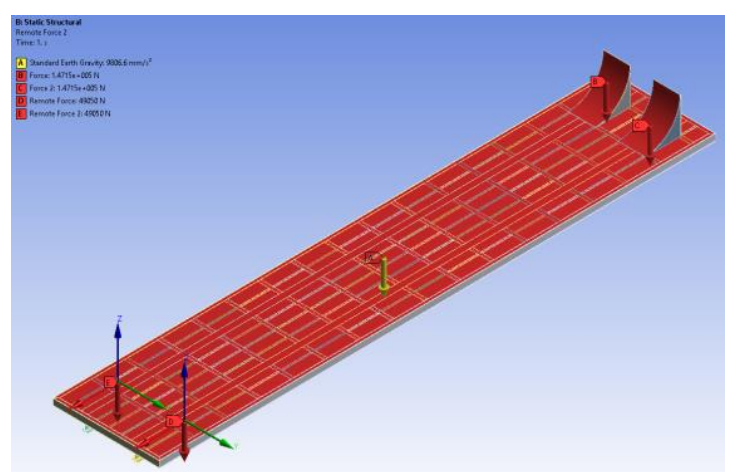

Figure 6. Forces that exert on the platforms (Horizontal position)

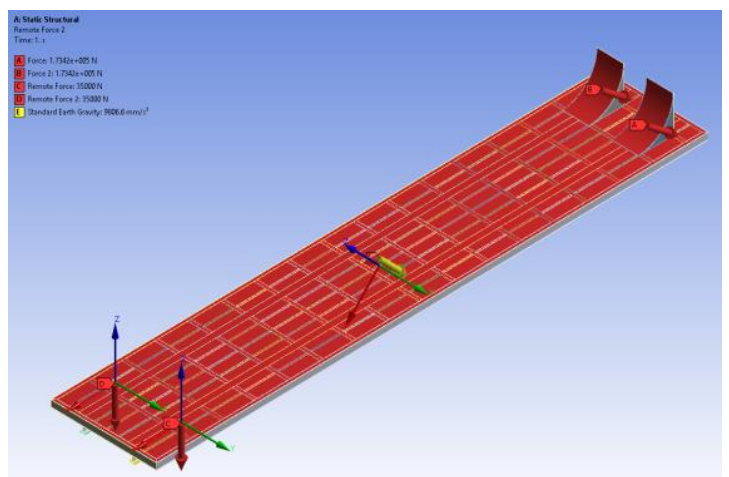

Figure 7. Forces that exert on the platforms $\left(45^{0}\right.$ inclined position) 


\section{RESULTS AND DISCUSSIONS}

All analyses were run for the applied boundary and loading conditions on HTUPs. The results were presented as von-Mises Stresses and Total Deformation.

Figures 8, 9, and 10 illustrate the von-Mises stress whereas figures 11,12 , and 13 are the results of total deformations at first scenario (horizontal position) of HTUP-1, HTUP-2, and HTUP-3, respectively. The analyses indicated that the highest stress occurred at the back-side of the platforms since the exerted force which is simulated the load of a truck is higher at the backside. However, highest deformation was found at the front-side of the platform. The reason of it may due to the distance between the place of the force with simulated the front axle of a truck and the fixed points where the hydraulic pistons would attache in application. The results of maximum von-stress and total deformations were found as $142,06 \mathrm{MPa}$ and $4,8039 \mathrm{~mm}$, for HTUP-1; 210,29 $\mathrm{MPa}$ and 4,7109 $\mathrm{mm}$ for HTUP-2; and $163,58 \mathrm{MPa}$ and $4,7423 \mathrm{~mm}$ for HTUP-3. Therefore, S235JR quality steel with $235 \mathrm{MPa}$ yield strength can be used HTUP-1; S355J2 quality steel which has $355 \mathrm{MPa}$ yield strength HTUP-2, and S275JR quality steel with 275 HTUP-3 may be used as the material of the platform's frame by considering safety factor is more than 1,65 .

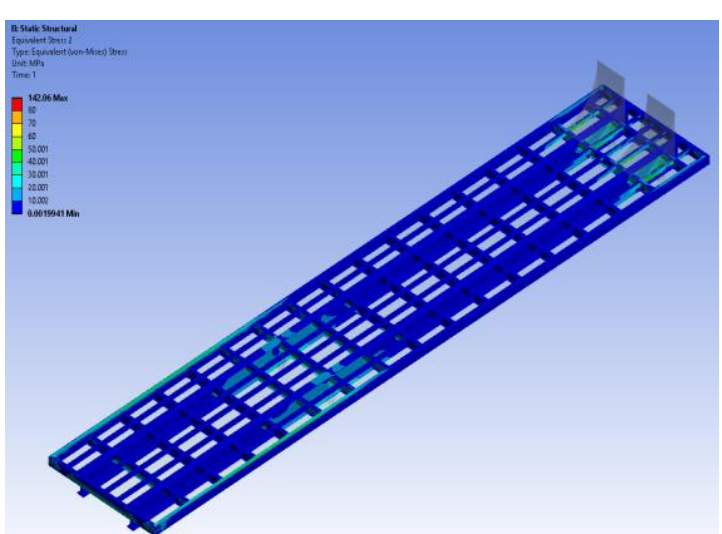

Figure 8. von-Mises stress distribution of HTUP1 at first scenario

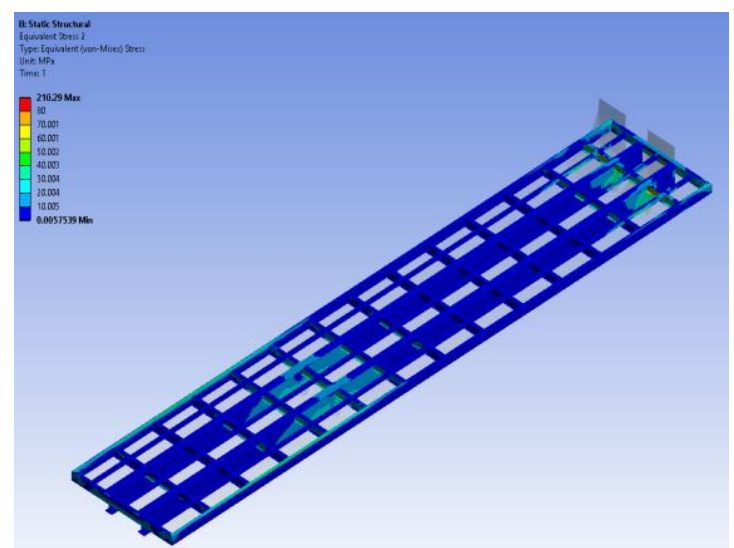

Figure 9. von-Mises stress distribution of HTUP2 at first scenario

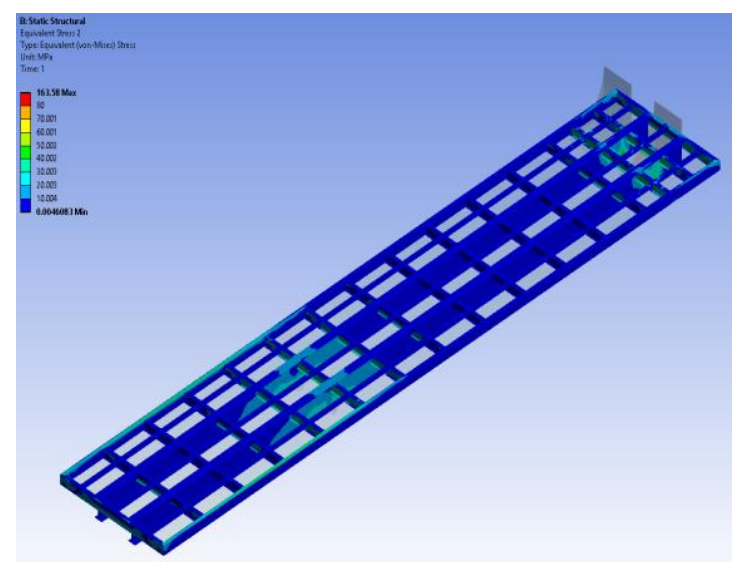

Figure 10. von-Mises stress distribution of HTUP3 at first scenario

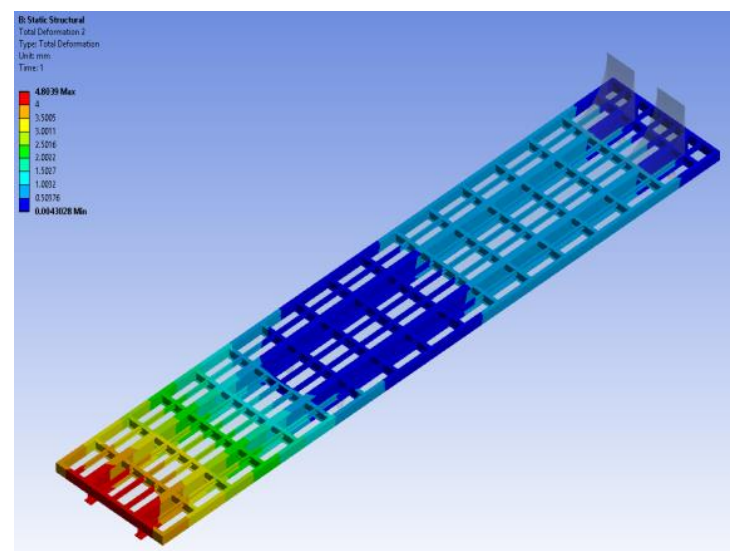

Figure 11. Total deformation of HTUP-1 at first scenario 


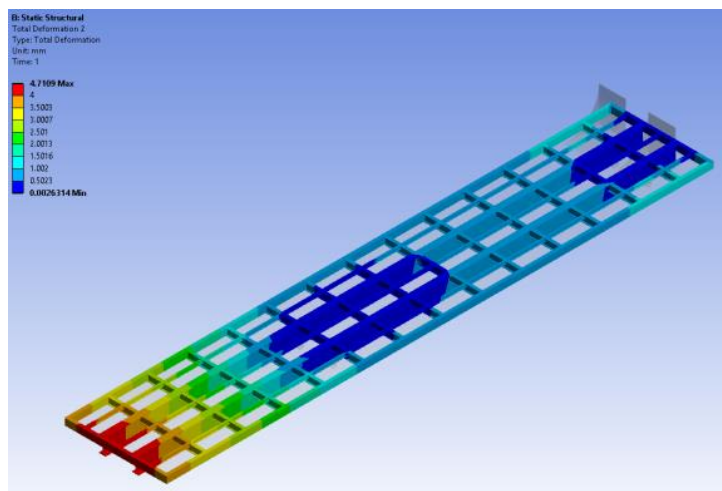

Figure 12. Total deformation of HTUP-2 at first scenario

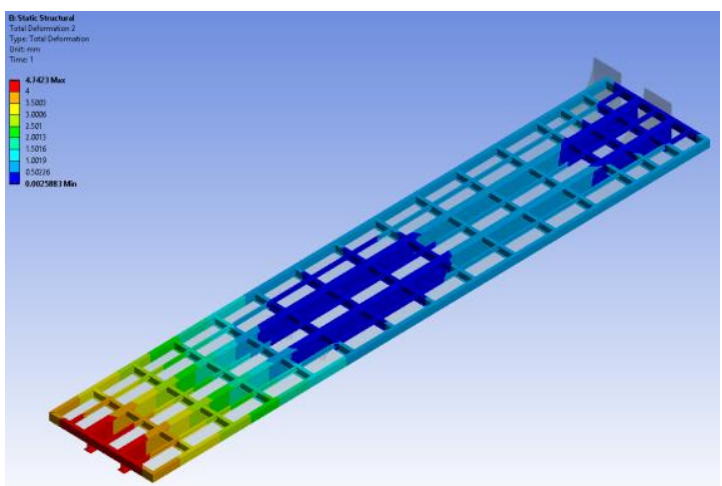

Figure 13. Total deformation of HTUP-3 at first scenario

At second scenario, forces were exerted by considering platform has $45^{\circ}$ angle with ground level. In this case, most of the forces that were exerted from a truck on the platform were applied at the rear axle. In this scenario, von-Mises stresses that exert on the frame of the platform is lower than its horizontal position since the stress was distributed more uniform by the sheets which are put in order to stabilize the trucks on the platform. The maximum von-Mises stresses were 93,411 $\mathrm{MPa}$, 105,76 $\mathrm{MPa}$, and 104,69 $\mathrm{MPa}$ for HTUP-1, HTUP-2, and HTUP-3, respectively. The results of stress distribution were shown in figures 14,15 , and 16 and total deformations of them were presented in figures 17,18 , and 19 . Since, in the second scenario, the load that exerts on front wheels was less, maximum deformation which occurred at the front edge of the frame is lower under these loading conditions. The maximum deformation is found out as $3,0466 \mathrm{~mm}$ which is $36,6 \%$ lower than the maximum deformation that observed in the first scenario.

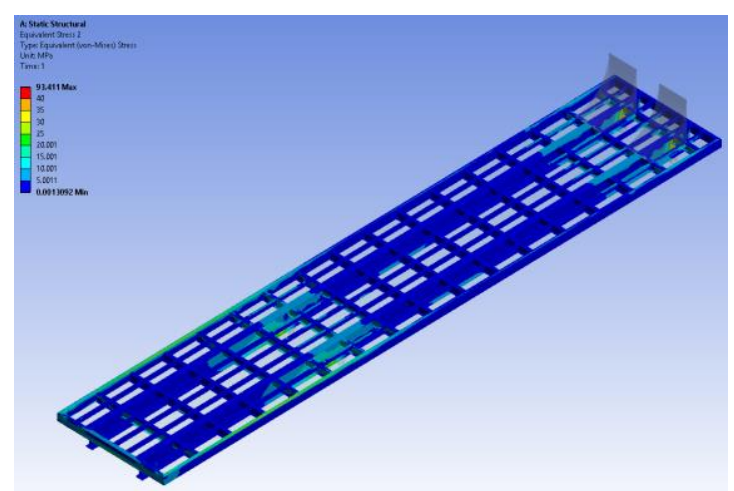

Figure 14. von-Mises stress distribution of HTUP1 at second scenario

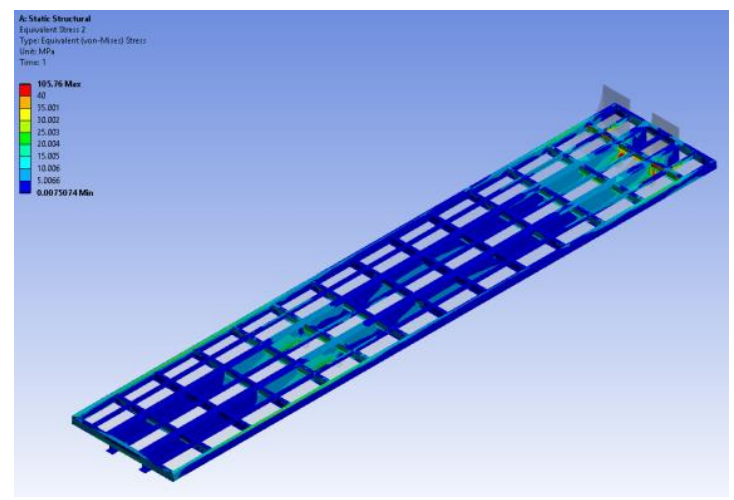

Figure 15. von-Mises stress distribution of HTUP2 at second scenario

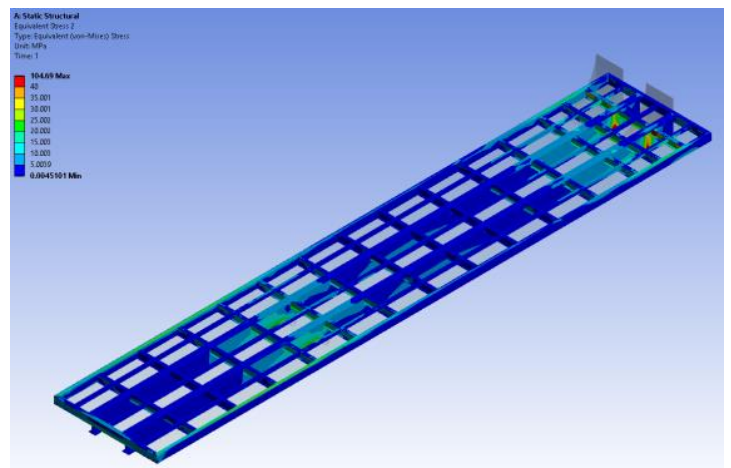

Figure 16. von-Mises stress distribution of HTUP3 at second scenario 


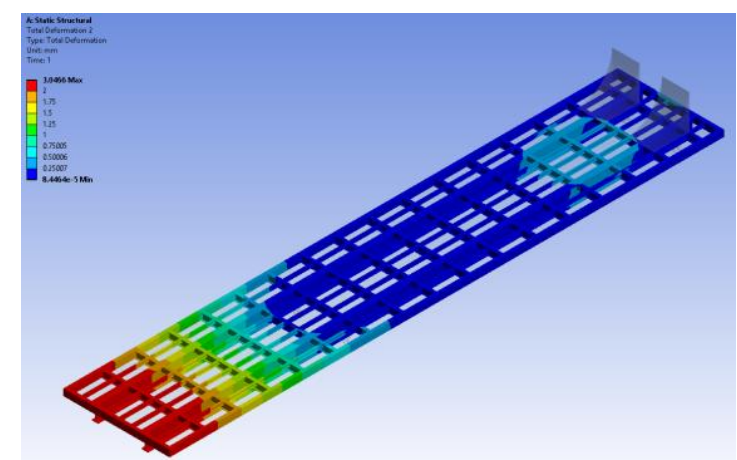

Figure 17. Total deformation of HTUP-1 at second scenario

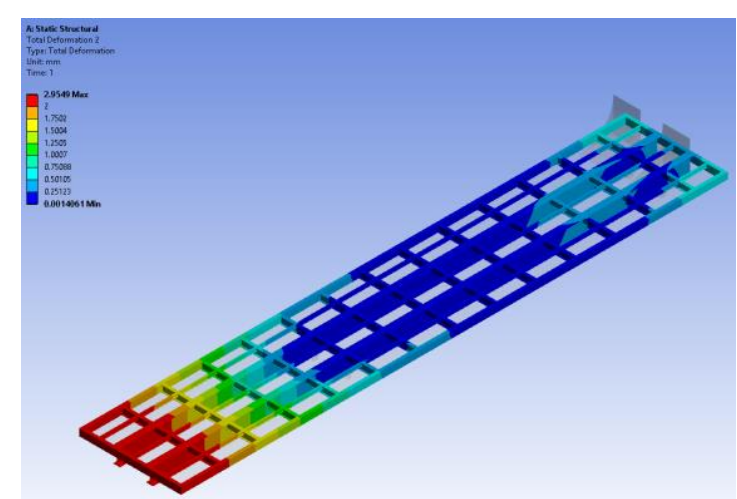

Figure 18. Total deformation of HTUP-2 at second scenario)

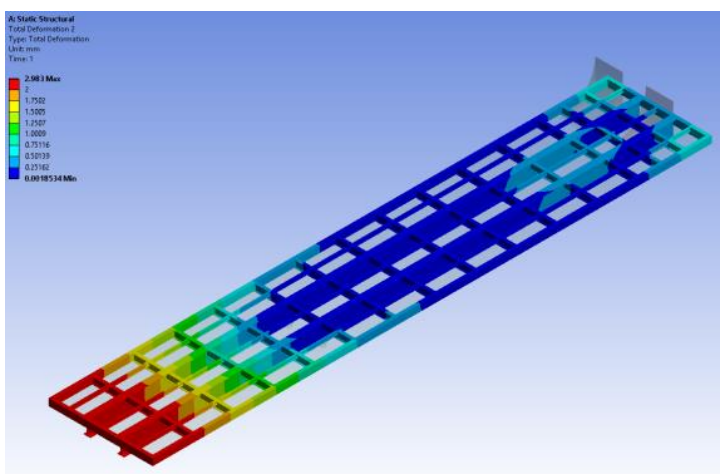

Figure 19. Total deformation of HTUP-3 at second scenario

According to results of von-Mises stress distributions, the steel type was decided for each HTUP design. HTUP-1 should be made of from S235JR quality steel, for HTUP-2 S355J2 quality steel should be used, and S275JR quality steel should be selected for HTUP-3 in order to ensure desired safety factor. With selected quality steels, minimum factor of safety is 1,65 , which is a ratio to tradeoff between safety, cost, and weight.

Table 2. Unit cost and total cost of frames

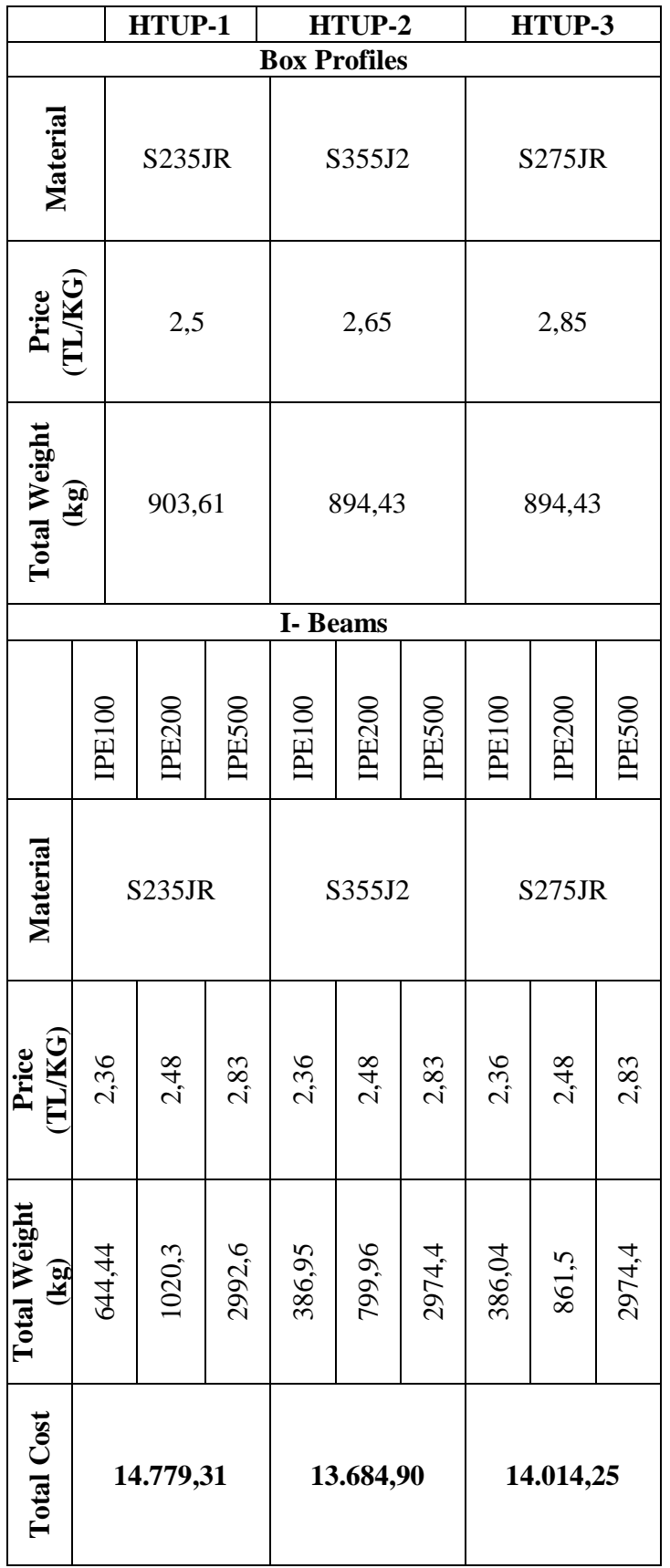


In table 2 unit cost and total cost of frames was given. The UHTC-2 has the lowest material cost whereas UHTC-1 has the highest one.

\section{CONCLUSIONS}

The objective of this study was comparison of three different UHTC frames by considering their stress and cost analysis. The stress analyses were carried out in 2 different service conditions of the platforms. The following summarizes were brought out:

- Different frames types were changed von-Mises stresses between $210,29 \mathrm{MPa}$ and $163,58 \mathrm{MPa}$ in the first scenario and 105,76 $\mathrm{MPa}$ and 93,411 $\mathrm{MPa}$ in the second scenario.

- Highest total deformation of the frames were occurred on UHTC-1 4,8039 $\mathrm{mm}$ and 3,0466 $\mathrm{mm}$ in scenario 1 and 2 respectively.

- According to stress distribution on platforms, the materials of HTUP-1, HTUP-2, and HTUP-3 was selected as S235JR, S355J2, and S275JR quality steels, respectively.

- Although the material of HTUP-2 has the highest unit price, the total cost of HTUP-2 was found as lowest material cost.

\section{ACKNOWLEDGEMENTS}

The authors are greatly appreciated to Adana Science and Technology University for providing financial support. This work is supported financially by Adana Science and Technology University Scientific Research Office under project no: 17103019 .

\section{REFERENCES}

1. Wu, J., Gao, J., Luo, Z., Brown, T.,2016. Robust Topology Optimization for Structures Under Interval Uncertainty. Advances in Engineering Software, Vol. 99, 36-48.

2. Silori, P., Shaikh, A., Nithin Kumar, K.C., Tandon, T., 2015. Finite Element Analysis of Traction Gear Using ANSYS. Materials Today: Proceedings, Vol. 2, 2236-2245.
3. Helou, M., Vongbunyong, S., Kara, S., 2016. Finite Element Analysis and Validation of Cellular Structures. Procedia CIRP, Vol. 50, 94-99.

4. Balomenos, G.P., Genikomsou, A.S., Polak, M.A., Pandey, M.D., 2015 Efficient Method for Probabilistic Finite Element Analysis with Application to Reinforced Concrete Slabs. Engineering Structures, Vol. 103, 85-101.

5. Bošnjak, S.M., Gnjatović, N.B., Momčilović, D.B., Milenović, I.L.J., Gašić, V.M., 2015. Failure analysis of the mobile elevating work platform. Case Studies in Engineering Failure Analysis, Vol. 3, 80-87.

6. Ren Y., Yu Y., Zhao B., Fan C., Li H., 2017. Finite Element Analysis and Optimal Design for the Frame of SX360 Dump Trucks. Procedia Engineering, Vol. 174, 638 - 647.

7. Covill, D., Blayden, A., Coren, D., Begg, S., 2015. Parametric Finite Element Analysis of Steel Bicycle Frames: The Influence of Tube Selection on Frame Stiffness. Procedia Engineering, Vol. 112, 34-39.

8. Nor, M.A.M., Rashid, H., Mahyuddin, W.M.F. W., Azlan, M.A.M., Mahmud, J., 2012. Stress Analysis of a Low Loader Chassis. Procedia Engineering, Vol. 41, 995-1001.

9. Hadi, M.N.S., Yuan J.S., 2017. Experimental Investigation of Composite Beams Reinforced with GFRP I-beam and Steel Bars. Construction and Building Materials, Vol. 144, 462-474.

10. Rivera J.A., Aguilar E., Cardenas D., Elizalde H., Probst O., 2016. Progressive Failure Analysis for Thin-walled Composite Beams Under Fatigue Loads. Composite Structures, Vol. 154, 79-91.

11. Li, Y., Shan, W., Shen, H., Zhang, Z. W., Liu, J., 2015. Bending Resistance of I-section Bamboo-steel Composite Beams Utilizing Adhesive Bonding. Thin-Walled Structures, Vol. 89, 17-24. 
